\title{
Effects of Carbohydrates upon the Rates of the Decomposition of Fish Muscle by Bactcria.
}

\author{
Masao KIMATA
}

(The Imperial Fisheries Institute, Tôkôy)

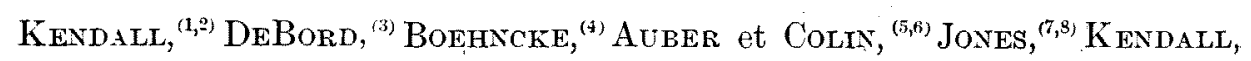
and Keithe, ${ }^{(9)}$ Glenn, ${ }^{(10)}$ Berman and RetTger ${ }^{(1)}$ Kendall, DAY and Walker, ${ }^{(12)}$ and Meyerhof and Burk ${ }^{(18)}$ have reported on the effects of carbohydrates upon nitrogenous metabolism by bacteria.

But so far as I am aware, nothing is known of the relation between the decomposition of fish muscle by bacteria and the compounds in question. The present paper embodies my observations on the effects of carbohydrates upon the rates of the decomposition of fish muscle by bacteria, and on the growth rates of bacteria in the fish muscle media containing carbohydrates.

\section{MATERIAL AND METHOD}

1. Cultural media:-One hundred c.c. of the fish muscle suspension were made by means of the previously, reported method, ${ }^{(14)}$ pipetted into a sterilized flask of 300 c.c., and added with an equal volume of sterilized $2 \%$ solution of carbohydrates.

2. Carbohydrates employed :-Monosaccharides: arabinose (pentose), glucose, levulose, galactose (hexose) ; Disaccharides : lactose, maltose (reducmg sugar), sucrose (non-reducing sugar); Trisaccharides: raffinose.

3. Organisms employed :-Pseudomonas fluorescens, Serratia marcescens, Achromobacter sp. (St. No. 36).

4. Procedure :-The same as the previously reported method ${ }^{(15)}$ was used. After standing for a definite time, $\mathrm{pH}$-values were determined and also total acidities were determined by reading off the quantity of $\mathrm{N} / 40 \mathrm{NaOH}$ as needed to neutralize 5 c.c. of the mixture, phenolphthalein being used as indicator.

\section{RESULTS}

The effect of various carbohydrates on the bacterial decomposition of the fish muscle varies with the kinds of bacteria and those of carbohydrates. So far as my experiments go, the rate of the bacterial decomposition of the fish muscle is seldom increased but mostly decreased. This decrease was accompanied by the bacterial fermentation of carbohydrates of the media. Hexose is generally most easily fermented by microorganisms. The cause of inhibiting action of these carbohydrates on the bacterial decomposition is not clear, 
but it appears to me that this action is probably due not only to the change of $\mathrm{pH}$ and of total acidity but also to the production of acids and other fermenting materials. The effect of carbohydrates on the growth rates of organisms is almost negligibly small as shown in Table 1 and Figure 1, although the final arnount of living cells is slightly influenced by them.

1. Pseudomonas fluorescens :-Hexose of carbohydrates employed has the greatest inhibitory power for the formation of volatile basic nitrogen and that of formol titrating nitrogen from the fish muscle.

These nitrogens are not formed in the medium containing glucose or galactose. In either case the $\mathrm{pH}$-value of media tends to become acidic, although that of glucose become smaller than that of galactose. Total acidity of the former increases with the decreasing $\mathrm{pH}$ value, and that of the latter increases at first, but decreasing gradually afterwards. The effect of levulose on the decomposition differs from that of glucose and galactose-action of proteolysis is nearly the same as that of the control within the first $3 \sim 4$ days, but after that the formation of volatile basic nitrogen and of formol titrating nitrogen is suddenly ceased, $\mathrm{pH}$ value becoming smaller and total acidity larger. Arabinose is one of monosaccharides, but its action differs from that of the above mentioned three, forming volatile basic nitrogen and formol titrating nitrogen very slightly, with $\mathrm{pH}$ value slightly smaller, and with total acidity almost unchanged within the first $8 \sim 9$ days.
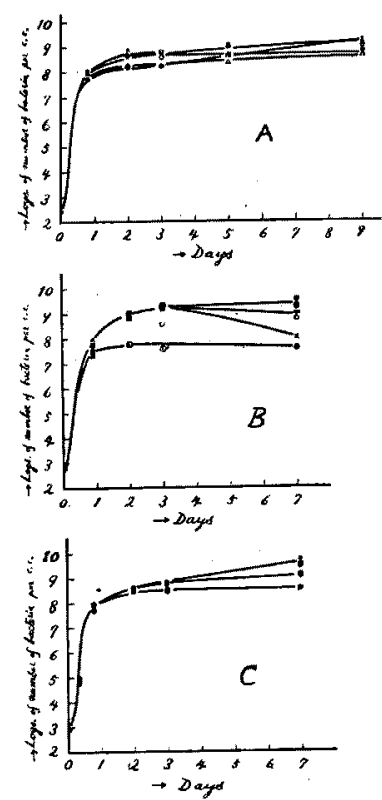

Fig. 1. Growth of bacteria. A. - Achromobacter sp. (St. No. 36) $B$...Pseudomonas fluorescens.

C.... Serratia marcescens.

O.... Control, $\otimes \cdots$ Arabinose, ○....Glucose, $\times \cdots$ Levulose, $\square$. . . Galactose, …. Lactose, $\checkmark \ldots$ Maltose, $\Delta$.... Sucrose, Soon after that $\mathrm{pH}$-value becomes larger, total $+\cdots$ Raffinose.

acidity becomes smaller, and the formation of the above mentioned nitrogens simultaneously take place. Maltose of disaccharies tends to increase the rates of the production of formol titrating nitrogen and that of volatile basic nitrogen for about 7 days, but then it suddenly ceases the formation of these nitrogens which are gradually decreased after that. This cause is not clear, but these nitrogens are very likly to be utilized together with other available carbon sources by microörganism. Until 7 days, $\mathrm{pH}$-value of the maltose media progresses to alkaline side just as the control does, but afterwards it almost ceases to change in spite of ever increasing alkaline tendency of the control. 
Table 1 Effect of various carbohydrates on the growth rate.

$g \cdots$ generation time (hour), $k \cdots$ velocity constant of the growth rate.

Pseudomonas fluorescens

\begin{tabular}{|c|c|c|c|c|c|c|c|c|c|c|c|c|c|c|c|c|c|}
\hline \multicolumn{2}{|c|}{ non } & \multicolumn{2}{|c|}{ arabinose } & \multicolumn{2}{|c|}{ glucose } & \multicolumn{2}{|c|}{ levulose } & \multicolumn{2}{|c|}{ galactose } & \multicolumn{2}{|c|}{ lactose } & \multicolumn{2}{|c|}{ maltose } & \multicolumn{2}{|c|}{ sucrose } & \multicolumn{2}{|c|}{ raffinose } \\
\hline$g$ & $k$ & $g$ & $k$ & $g$ & $k$ & $g$ & $k$ & $g$ & $k$ & $g$ & $k$ & $g$ & $k$ & $g$ & $k$ & $g$ & $k$ \\
\hline 1.34 & 0.52 & 1.43 & 0.49 & 1.41 & 0.49 & 1.28 & $0-54$ & 1.41 & 0.49 & 1.43 & 0.49 & 1.32 & 0.53 & 1.37 & 0.51 & 1.34 & 0.52 \\
\hline
\end{tabular}

Serratia marcescens

\begin{tabular}{rl|ll|ll|ll|ll|ll|ll|ll|l|l}
\hline 1.26 & 0.55 & 1.27 & 0.55 & 1.30 & 0.53 & 1.24 & 0.56 & 1.27 & 0.55 & 1.24 & 0.56 & 1.22 & 0.57 & 1.19 & 0.53 & 1.23 & 0.56 \\
\hline \\
\hline 1.19 & 0.58 & - & - & 1.14 & 0.61 & 1.13 & 0.61 & 1.20 & 0.58 & 1.12 & 0.62 & - & - & 1.12 & 0.62 & 1.18 & 0.59 \\
\hline
\end{tabular}

Total acidity slightly decreases. It seems that the decomposition of the fish muscle is not influenced by lactose, sucrose, and raffinose, although it is slightly prevented by lactose. Effect of carbohydrates employed on the rates of the growth is nearly null, but that on the final amount of living cells is little larger, smallest when glucose is presence.

2. Serratia marcescens :- It seems that the decomposition of the fish muscle is not influenced by raffinose and arabinose. By lactose the velocity of the decomposition is slightly decreased, total quantity of volatile basic nitrogen and that of formol titrating nitrogen produced are less than those of the control, pH-value gradually turning to alkaline until about 9 days and then to acid side. Total acidity becomes greater until about 5 days with its suspension until about 9 days when it becomes greater again. Glucose, levulose, sucrose or maltose inflict the same effect on the decomposition of the fish muscle for $7 \sim 8$ days, increasing quantity of the formation of volatile basic nitrogen and of formol titrating nitrogen very slighty, making $\mathrm{pH}$-value smaller and total acidity larger. In the case of glucose, after this period the decomposition is ceased and $\mathrm{pH}$-value becomes more larger. But in the cases of other three, the decomposition is much more progressed. Effect of galactose on the decomposition is intermediate between that of lactose and of the above mentioned four, changing $\mathrm{pH}$-value so much, "and having trend of change of total acidity nearly the same as that of lactose, with its value slightly smaller.

3. Achromobacter sp. (St. No. 36) :-The decomposition of fish muscle by this germ was retarded by the following carbohydrates arranged in deseending order : sucrose $>$ glucose $>$ galactose $>$ levulose $>$ raffinose $>$ lactose. It may be mentioned that glucose, galactose and levulose differ vop slightly from each other in the effects under condition. The formation of volatile basic nitrogen and of formol titrating nitrogen is more inhibited by sucrose than 

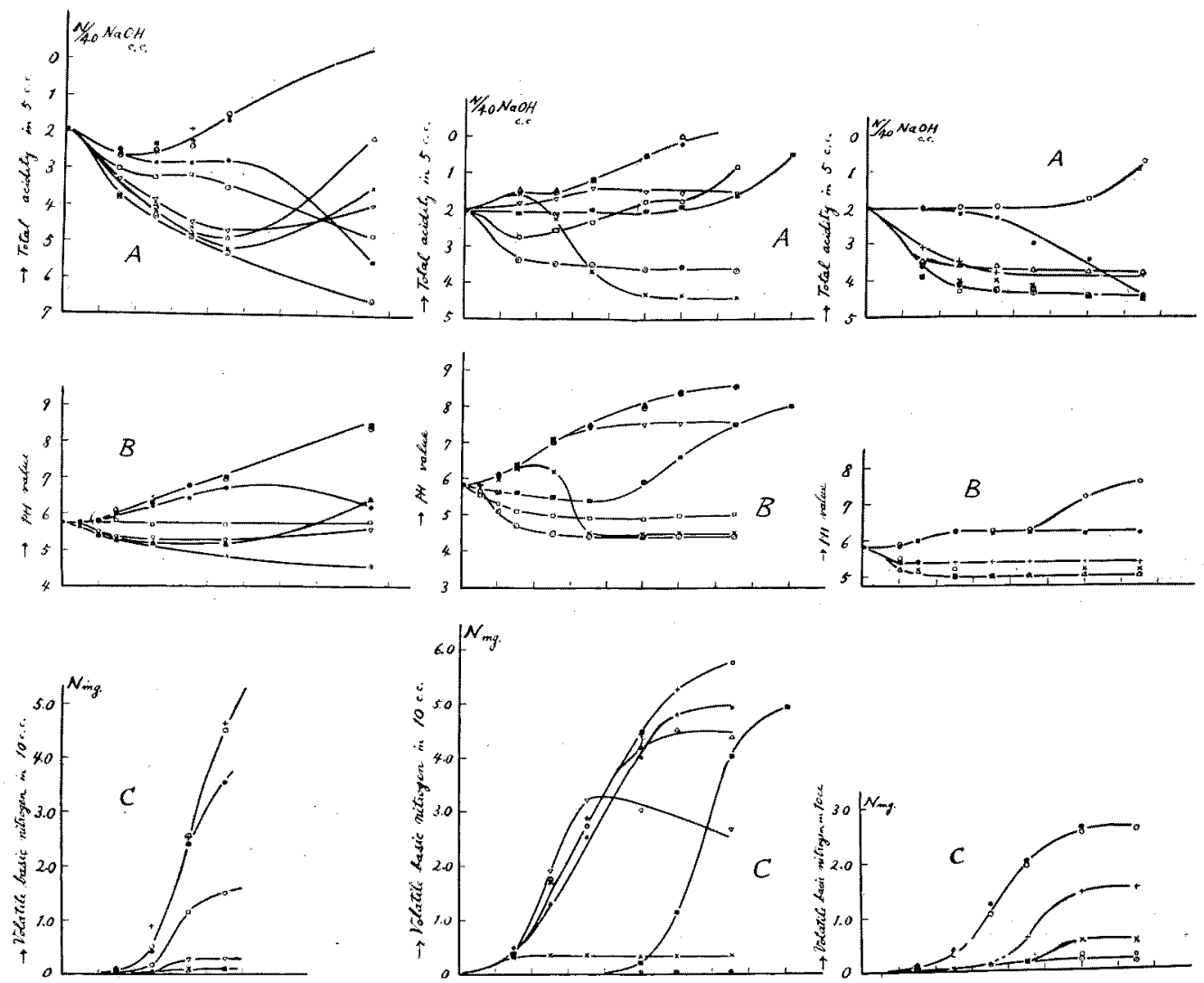

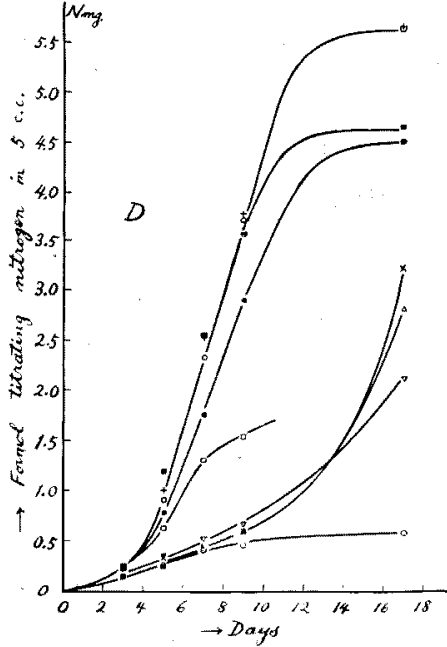

Fig. 2. Serratia marcescens.

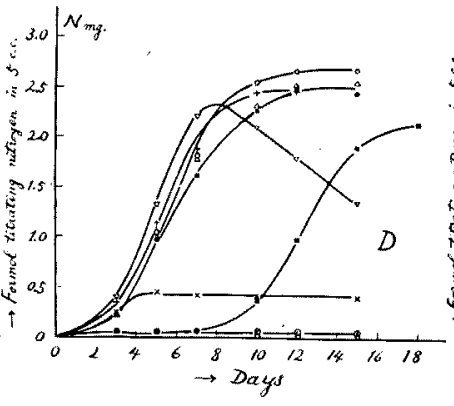

Fig. 3. Pseudomonas fluorescens.

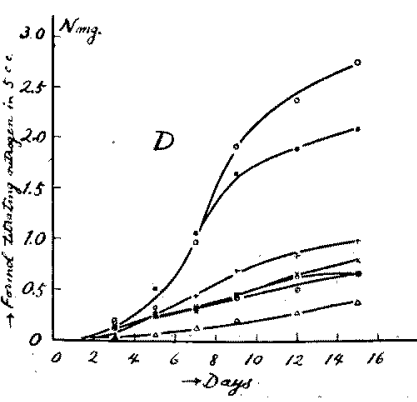

Fig. 4. Achromobacter sp. (St. No. 36)

$A \cdots$ Total acidity plotted against time. $C \cdots$ Volatile basic nitrogen plotted against time, $B \ldots$ pH-value plotted against time $D \cdots$ Formol titrating nitrogen plotted against time Various marks are the same in the Fig. 1 . 
by the above mentioned three, but total acidity is rather smaller and $\mathrm{pH}$-value is nearly the same.

\section{LITERATURE}

(1) Kendall, A. I. :-Studies in bacterial metabolism, LXVII. Carbohydrate identification by bacterial procedures. J. Inf. Dis., 32, 1923, 362 ,

(2) Kendall, A. I. :--Bacterial metabolism. Physiol. Rev., 3, 1923, 438.

(3) DeBord, G. G. :-Certain phases of nitrogenous metabolism in bacterial cultures. J. Bact. 8, 1923, 7 .

(4) BoEHNoke, K. E.:- Über die Abspaltung des Anaphylatoxins aus Meníngokokken. Z. Hýg., 72, 1912. 304 .

(5) Acber, E. et Corrs, H.;-Action des sucres sur la fonction pigmentaire, du bacille pyocyanique. Compt. Rend. Soe. Biol., 75, 1913, 25.

(6) Auber, E. et Colin, H.:-Influence des sucres sur la transformation bactérienne des substances organiques azotées en sels ammoniacaux. Compt. Rend. Soc. Biol., 76, 1914, 835.

(7) JoNes, H. M.:- The protein-sparing action of utilizable carbohydrates in cultures of certain sugar-fermenting organisms. J. Inf. Dis., 19, 1916, 33.

(8) JoNes, H. M. :-Effect of carbohydrate on amino acid utilization of certain bacteria. J. Inf. Dis., 27, 1920, 169.

(9) KENDALL, A. I. and Keith, H. R.:-Studies in bacterial metabolism. LXXVI. Nature of soluble proteolytic enzyme of Bacillus proteus. J. Inf. Dis., 38, 1926, 193.

(10) Guenn, T. H.:-Variation and carboyhdrate metabolism of bacilli of the Proteus group. Centbl. Bakt. (etc.), Abt. 1, 58, 1913, 481.

(11) Berman, N. and Rettger, L. F. - Infinence of carbohydrate on the nitrogen metabolism of bacteria. J. Bact., 3, 1918, 389.

(12) Kendatu, A. I, DAY, A. A. and Walkek, A. W. :-Studies in bacterial metabolism. J. Amer. Chem. Soc., 36, 1914, 1962

(13) MeYerhor, O. und RURK, D. :-Über die Fixation des Luftstickstoffs durch Azotobacter Z. phys. Chem., Abt. A., 139, 1928, 117.

(14) Kimata, M:-Effect of halogen ions upon the growth rate of bacteria and on the decomposition of fish muscle, Bull. Jap. Soc. Sci., 4, 1936, 294.

(15) Krmata, M. ;-The rates of the decomposition of fish muscle by various kinds of bacteria. Bull. Jap. Soc. Sci., 5. 1936, 77. 